\title{
Aporias of National Cinema?
}

\author{
JPaul S. Manzanilla
}

Patrick F. Campos's The End of National Cinema: Filipino Film at the Turn of the Century (2016) highlights the durable entanglements of cinema and the Philippine nation in the last hundred years. Following are my initial thoughts on the many issues which the work has raised.

The book's significant contribution is in the interrogation of the concept and fact of the "nation" and the "national" by various filmmakers and films, state and cultural institutions, critics, and consumers of film. The nation in, beyond, and through cinema is problematized in the process of its being contested by the official nationalism of the state (tackled in almost all of the chapters), popular struggles from below and the margins (chapters three to seven), deterritorializing and reterritorializing efforts by the Filipino diaspora and foreigners (chapter eight), and the involved optics of the "foreign" that view and appropriate the Filipino in films (chapters eight and nine). However, the author's own definition of what national cinema is should be made, with a resolution of all the debates on nation-construction in films which he diligently presented as a formidable starting-point. Is he defining national cinema within the domain of the nation-state, that is, a crudely nominalist paradigm that territorializes a techno-artistic, economic, and cultural creation inside geopolitical boundaries? Studies of the nation as fastened to a host of objects and phenomena should address the dilemma of nationalism, its being politically powerful yet philosophically poor (Anderson, 1983, 5).

A reader might assume that the author is trying to build up bodies of works called national cinema similar to "national literature," having a related but different set of challenges. One might also think that the invocation of national cinema is a bid in the battle for a place in a "world republic of films," to use Pascale Casanova's term for world literature (2004). These are important projects, especially because in a development akin to colonialism's inextricability from nationalism (in fact, its root cause), the specter of Hollywood predominantly haunts national cinemas. One wonders why American cinema or Hollywood is not problematized as $a$ national cinema in general; it is actually against Hollywood which most, if not all, national cinemas define themselves (as discussed from chapters six to nine). At the same time, there is a need to examine whether Hollywood is indeed foreign to all other national cinemas (Thomas Elsaesser as cited by Crofts, 1993), when so many technological, stylistic, and even thematic sources and influences come from it. Eddie Romero's Hollywood career provides crucial insights on how a Filipino filmmaker confronted his country's troubled history with 
the United States within filmic coproductions with an "erstwhile enemy" (Hawkins, 2006).

It is to his credit that the author, an independent film critic, probes the constitutions of both national and independent cinemas within the Philippine and international film festival circuits and the global market of films (chapters one to five). For it is in the various scriptwriting and filmmaking competitions and festivals, with the Cinemalaya Film Festival being the most prominent locally, where the conceptualization and direction of films continually grapple with various subject-formations-from the village and communal, to a host of ethnic, sexual, religious-spiritual, and national subjectivities. Not only do filmmakers, by way of advocacy or personal struggle, create movies highlighting these identities, but state and private institutions catechize them to make productions which can be slotted to identitarian categories. It is in the context of international film festivals where films, which happen to be made by Filipinos or in the Philippines, come to be defined as constituting "national" cinema. Whether a film is truly or authentically about "the nation" of its "origin and name" is often ignored internationally, but it is fiercely contested within the country when it casts the nation in a "bad" light. Controversies over so-called "poverty porn" highlight the ethical and moral problems of filmmaking about the poor, which still constitute majority in the Philippine population and therefore something to always consider in representing the nation, just as they reflect the anxieties of the elite and middle classes concerning how the(ir) country should be represented. Recall how nineteenth century ilustrados were enraged by the staging of "primitive" Filipinos in the Madrid 1887 Philippine Exhibition (Thomas, 2016; Campos notes the same on p. 212). This is not to deny the relevance of "strategic essentialism" (Spivak, 1988) which many artists enact in order to obtain recognition and, perchance, call for positive changes in the societies they represent, similar to earlier efforts of postcolonial intellectuals.

Questions of "identity" and "uniqueness" have also always preoccupied national cinema, and the search for and assertion of them are seen to be standard requirements for nationalizing cinemas (see Choi, 2011 for an important discussion on the critical issues of national cinema in the present). The problem of the native, in its appearances as nature, environment, the indigenous, and the ethnic, has traditionally been considered as the zero point or raw material of the national. Campos admirably expounds on how the national is actually built upon the inexhaustible cultural resources of the people through his discussions of the filmic folklore (chapter seven), action films (chapters six and seven), and the cinema of Kidlat Tahimik (chapter three). These resources are not foolproof, however, as there are many 
pernicious conformist beliefs that rework the nation in problematic ways. Such phenomenon is exemplified by horror films that make monstrosities out of decisions and actions that contest conservative family values (tiyanak as aborted babies, for example); dramatic films that resolve class struggles within the text, as when the main narrative strategy is to portray the rich and poor characters as marrying; and action and drama films that exile the protagonists to the pastoral world in order to rehabilitate themselves through a purification process afforded by the pristine countryside and the feudalistic and patriarchal rural family values that nurture them in the first place (for an insightful discussion on how indigenous customs and traditions have been utilized for malevolent ends, see Guillermo [1995], which remains to be an important text of cultural analysis). Extrafilmically, the election and deposition of Joseph Estrada demonstrate how such values remold Philippine state and society in execrable ways, therefore calling upon us to realize that in the native and indigenous also lurk the evil in our society (Lav Diaz has made riveting films on this predicament) a fact that complicates and even contradicts what Zeus Salazar apotheosizes in "Erap" and other action stars (discussed in a section on action movies, pp. 419-434) and all things "Filipino."

As the nation went through tumultuous changes in the last thirty to forty years-changes that rework how cinema itself is to be interpreted and changed in turn - the author touches upon how radical discourses on independent cinema have themselves treaded on shifting grounds. Campos (2016) asserts:

The 'artistic freedom and democratization' that digital technology has encouraged and the systematic move to 'democratize, de-centralize and Filipinize' state institutions, initiated in the [Cultural Center of the Philippines] by [its then Artistic Director Nicanor] Tiongson in the post-Marcos dispensation, as well as the splintering of the Philippine Left in the years leading to 1986, have contributed to the deradicalization of discourses on independent cinema. (p. 258)

This is an important claim that highlights the supposed inverse relation in states of emergency of freedom, on the one hand, and artistry and substance, on the other, by positing democratization as an antidote to radicalism; that is to say, in the absence of the enemy, the filmmaker and the film become thematically and stylistically enervated. This formulation challenges us to unpack the terms of deradicalization itself. It is as though Philippine cinema can only have a radical edge when it has an enemy in the 
classic mold of a dictatorship. Moreover, this thesis compels us to ask, in a Benjaminian sense, whether the enemy has been extinguished or ceased to be victorious, when iniquitous-even authoritarian-practices persist in the world of filmmaking, hence necessitating a reradicalization of a more penetrating kind. Numerous cases of film censorship, as well as the various manipulations and maneuverings - from the production aspects up to the marketing and international promotion-of Filipino films, point to a more pervasive and tentacular kind of conservatism besetting contemporary cinema (the case of the film MNL 143 [2012] is reviewed by the author on pp. 262-263). Censorship through the government's Movie Television Review and Classification Board (MTRCB), non-state bodies such as the Catholic Bishops Conference of the Philippines (CBCP) and other pressure groups, sectarian schools, and privately owned theaters that decide which films are to be shown in how many cinemas for a certain period of time (think, for example, of the SM Cinemas that have banned R-18 movies), necessitate more dynamic discourses on independent cinema that contend with political economic factors inseparable from cultural and social considerations. The crucial aspects of distribution and exhibition significantly determine what we have come to behold as "indie" and national cinema, especially now when more and more films are being made independent of the resources of big private and state bodies.

Campos tackles these crucial issues, but, in the end, he must clarify what he means by the "end" of national cinema. The fact of transnationality does not nullify cinema's nationality; it all the more emphasizes the enduring construction of the national (see Choi, 2011, 187-189 for the renewed terms of this debate). One may argue: it is not that the nation should be defended in the face of the transnational; it is that we can renationalize through the transnational, that it is in dialectical engagement with the inter/transnational that the national comes into being. Does "end" in the monograph's title mean the "goals" or "purposes" of national cinema? If so, the book has achieved some measure of success in laying out national cinema's objectives, however disparate and scattered in treatment. Or, playing on the word's double meaning, is the author referring to "end" in the sense of the "ending" or "expiration" of national cinema? This is a more difficult project, for it ultimately raises the question of address - the Filipino people in all their complexities - that the national must always contend with. Perhaps it is with the problem of the addressee that a full accounting of what national cinema is and ought to be should begin and also end. 


\section{References}

Anderson, B. (1983). Imagined communities: reflections on the origin and spread of nationalism. London: Verso.

Casanova, P. (2004). The world republic of letters. M. B. Devoise (Trans.). Cambridge, MA: Harvard University Press.

Campos, P. F. (2016). The end of national cinema: Filipino film at the turn of the century. Diliman: University of the Philippines Press.

Choi, J. B. (2011). National cinema: an anachronistic delirium? Journal of Korean Studies 16(2), 173-191.

Crofts, S. (1993). Reconceptualizing national cinema/s. Quarterly Review of Film and Video 14 (3), $49-67$.

Guillermo, A. (1995). Mga istratehiyang ideolohikal sa katutubong tradisyon. In L. Quindoza-Santiago (Ed.), Mga idea at estilo: komposisyong pangkolehiyo sa wikang Filipino (pp. 21-39). Quezon City: University of the Philippines Press.

Hawkins, M. (2006). The colonial past in the postcolonial present: Eddie Romero's "cavalry command." Plaridel: A Journal of Philippine Communication, Media, and Society 3(2), 23-48.

Spivak, G. (1988). In other worlds. New York: Routledge

Thomas, M. C. (2016). Orientalists, propagandists, and ilustrados: Filipino scholarship and the end of Spanish colonialism. Mandaluyong City: Anvil Publishing, Inc.

JPAUL S. MANZANILLA is a graduate student at the Department of Southeast Asian Studies of the National University of Singapore. He is doing research on the history of photography in the Philippines in relation to nation-building and critiques of nationalism, global and cosmopolitan techno-artistic practices, and the trajectories and developments of multiple modernisms (corresponding author: jpaulmanzanilla@gmail.com). 
